\section{Becoming well oiled}

India is increasing its investment in oil, and the aim is self-sufficiency. Our correspondent in Jullundur reports on a vital aspect of the sub-continent's energy equation

FOR over two years now, India has been groaning under the weight of her mounting oil-import bill. From around 3,000 million rupees a year before the 1973 Arab-Israeli war it is now running close to 12,000 million rupees-accounting for a third of her entire export earnings and a quarter of the total value of her imports. This is despite the fact that the Government, through a number of fiscal and other measures taken in early 1974, has managed to limit consumption and to curb the rate of growth of demand for oil. These measures remain in force.

Consumption rose in 1975 by only $2.7 \%$, from 21.74 million tonnes to 22.34 million tonnes, the 1974 figure being substantially lower than an estimated 25 million tonnes calculated on the basis of an earlier average annual growth rate of about $9 \%$. Consumption of petrol during 1975 , at 1.25 million tonnes, was slightly lower than the 1974 figure of 1.28 million tonnes, despite a considerable increase in the number of powered vehicles in the country; the items contributing to increased consumption of petroleum (and products) included naphtha (14.5\%), kerosene $(5.5 \%)$, high-speed diesel $(4.7 \%)$, furnace oil $(0.5 \%)$ and cooking gas $(14.3 \%)$. The increase in the offtake of naphtha was largely due to better capacity utilisation by fertiliser manufacturing units, while good rains helped dampen demand for diesel for agricultural purposes which was running some $12 \%$ higher during the first six months of 1975 compared to the same period in 1974.

India has been meeting only about a third of her oil requirements (including related products) from indigenous sources-mainly onshore wells in the states of Assam and Gujarat. She has had to import the rest from various oil-exporting Arab countries and Iran through bilateral agreements. The Union Petroleum and Chemicals Minister, Shri K. D. Malaviya, recently told the Parliamentary Consultative Committee attached to his Ministry that, because of India's adverse balance-ofpayments and foreign exchange positions, the situation regarding imported oil was likely to be very difficult during 1976. Neither was it known how and when OPEC's oil facility for developing countries would be set up, nor when results would start flowing from the ongoing "north-south" conference. The country expected to produce 9.5 million tonnes of oil this year, Shri Malaviya told the committee, and his ministry was making all possible efforts to ensure an import of 14 million tonnes from external sources to meet the country's essential requirements. [It has since been reported that arrangements have now been made for the import of a major part of the crude oil India needs from other countries].

India has passed through a very difficult period but, while she is still not completely out of the woods, pressure seems to have eased somewhat due to an all-round improvement on the energy front. Among other things, coal production has increased enough to wipe out scarcities, and power generation is presently pretty close to meeting all requirements so that power cuts imposed in most states have been withdrawn. While much of the improvement has come through better management and better performance by both man and machine, good and plentiful rains during 1975 have played no mean part in transforming the picture.

For all the havoc it has wrought on the country's economy, the oil crisis has also done a few good things: the Oil and Natural Gas Commission (ONGC) has been stirred into vigorous action and its redoubled efforts to find more oil onshore and offshore are beginning to yield results. From onshore fields in Assam and Gujarat, production this year is expected to be more than 8.2 million tonnes compared to 7.5 million last year. In three to four years' time, according to the Petroleum and Chemicals Minister, the figure will go up to 11 million tonnes.

Production could commence shortly from India's first offshore wells in the

\section{Science and religion}

If circulation figures of periodicals and journals are any indication, religious subjects continue to score over scientific ones in popularity among the literate population in India, which has the world's third largest scientific and technological community. According to a recent study, there were 927 scientific and technical journals (all languages) compared to 1,221 religious and philosophical ones in the country by the end of 1973 , and circulations of the latter went up by more than the former over the decade 1963-1973.

Broken down by language, the figures for the circulation of Bengali,
Bombay High region. Two developmental wells, along with other installations including submarine pipelines to take oil to the shore, are nearing completion. Production will start at the rate of 2 million tonnes a year by the end of 1976, and will gradually be stepped up to 10 million tonnes by the end of the decade. While the ONGC explores and exploits the Bombay basin, two foreign firms are working on the Bengal and Kutch basins. The very first well drilled in the Bay of Bengal was reported to be oil bearing, raising hopes of further breakthroughs. [The Minister recently announced an oil discovery of "very great significance" at the Bassein structure off the western coast].

In 1974, the ONGC acquired three new vessels, two for drilling in the Bombay High region and a third for seismic surveys in the continental shelf near Madras. The Petroleum Ministry has also set up a "deeper continental shelf" project to explore the $20,000 \mathrm{~km}$ region west and north-west of the Bombay High area. Various steps are also being taken to make the country self-sufficient in the manufacture of all types of equipment needed for onshore and offshore exploration and production of oil. The first country-made rig is expected to be available in about two years' time. A variety of oil-field equipment is already being manufactured in India, and its production is being stepped up.

India has also entered into agreements with Iran and Iraq to look for oil in these countries. According to the Petroleum Minister, some 750,000 tonnes of Rustum crude from India's exploration venture in Iran will be brought to India this year.

Before the turn of the century, India is expected to become selfsufficient in crude oil. Some optimists think she could even become an exporter of oil by the year 2000 .

Tamil, Kannada and Gujarati science periodicals showed a downward trend during the decade, whereas those of the religious journals in these languages went up over the same period. Marathi, the language of the state of Maharashtra, had the unique distinction of having more readers of scientific journals than those of the religious ones. Urdu was found to be another language with a distinctionit showed an increase in readership of scientific journals with a simultaneous decrease in circulation of the religious periodicals. In English and Hindithe two languages with the largest proportion of periodicals on all subjects-readers seemed to prefer religion to science. 